\title{
Citizenship and \\ Politics of Belonging \\ - Inclusionary and Exclusionary Framings of Gender and Ethnicity
}

\section{By Ann-Dorte Christensen AND BIRTE SIIM}

Is the notion of intersectionality good or bad? The article argues that intersectionality is double-edged. It can be a fruitful way to analyse the intersections between different categories. But intersectional arguments can also be part of an exclusionary framing, which constructs social distinctions between 'them and us'.

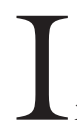

ntersectionality

is not a theory. In our view it is a methodological approach, which makes it possible to do multi-faceted analyses, which include multiple inequality categories. We argue for a more reflexive understanding of intersectionality in academic debates in relation to different theoretical paradigms and concepts. Further, we argue for a more dynamic notion of intersectionality in relation to how it is used in political debates.

The purpose of the article is to explore the intersectional approach in academic debates in relation to citizenship and politics of belonging and to discuss the doubleedged framings of gender and ethnicity in political debates. The first section gives a brief presentation of intersectionality in relation to the two main concepts and proposes a multi-level model for analysis. On this basis, the second section investigates the intersections of gender and ethnicity in political debates about the construction of national belongings. The Danish hijab case 
illustrates the contested use of intersectional arguments in political debates. We argue that the framing of gender and ethnicity is dynamic and contextual and may have both inclusionary and exclusionary meanings and effects. The example shows how political actors (mis)use the intersection of gender with ethnicity in order to reaffirm differences and inequalities between women - between the white majority and the Muslim minority.

\section{MULTILAYERED CITIZENSHIP AND POLITICS OF BELONGINGS}

Citizenship conceptualizes who is included and who is excluded in the national communities, e.g. who is defined as being 'inside' and who is 'outside' society. T.H. Marshall's classical notion of citizenship focuses on the inclusion of the working class in society and refers to an ideal about equal civil, political and social rights for all who live legally in the country (Siim 2000). In this tradition scholars often differentiate between three main dimensions of citizenship: a) equal status, rights and obligations; b) political participation and citizens' voice; and c) political identities and belonging (Bellamy et al. 2003).

Citizenship is gendered, and feminist research has revised the classical model's focus on class and has explored the inclusion of women and marginalized social groups in politics and society with a focus on the relation between wage work and care work (Lister et al. 2007). The notion of 'lived citizenship' refers to peoples' practice and identities to "...the meaning that citizenship has in peoples' lives and addresses how peoples' social and cultural backgrounds affect their lives as citizens" (Lister et al. 2007: 168). The citizenship approach can be used to illuminate the tensions in liberal democracies between principles of equality and recognition of diversity; between concerns for gender equality and respect for the culture and religion of ethnic minorities (Siim and Squires 2008).

Globalization and increased migration has been followed by problems with integration of immigrants and refugees in the national communities and has challenged the classical citizenship model attached to the nation state (Beck 2002). One group of scholars has proposed a post-national model with a transnational dimension (Soysal 1994, Yuval-Davis 1997). Another group has proposed a multicultural model based on diversity and accommodation of cultural and religious rights (Kymlicka 1995, Modood 2006).

Nira Yuval-Davis' work has explored the linkage between national belongings and citizenship from a gender perspective. Her approach provides elements for a rethinking of the citizenship approach, because it addresses the double challenge from diversity and transnationalism. She situates citizenship in a transnational context and presents the concept of 'belonging' as a way to enrich and clarify the discussions of contemporary citizenship linked to the notion of 'multi-layered citizenship'. The main argument is that people are no longer primarily connected to the nation state but are simultaneously citizens in more than one political community. At the same time the role of the nation states is changing towards a growing securitization of today's borders and boundaries (Yuval-Davis 2007: 561-63).

Yuval-Davis' approach makes a crucial distinction between 'belonging' and 'politics of belonging'. 'Belonging' refers to emotional attachment and to feeling at home and feeling safe. 'Politics of belonging' refers to “....specific political projects aimed at constructing belonging in particular ways to collectives that are, at the same time, themselves being constructed by these projects in very particular ways" (Yuval-Davis 2006a: 197). The major part of Yuval-Davis' work is concerned with 'politics of belonging' with demarcations of 
who is 'in' and who is 'out' of communities, labelled "the dirty work of boundary maintenance" (Yuval-Davis 2007: 563).

We agree that 'citizenship' and 'belonging' must be founded on intersectional perspectives because discussions of these issues tend to homogenize the differential meanings of categories such as 'blacks', 'women' etc. (Yuval-Davis 2007: 565-66). Arguably, the transnational approaches tend to overestimate the fluidity of identities and underestimate the institutional and discursive power relations, e.g. the political institutions of the nation state and the power relations at the transnational and local levels. We thus propose a multilevel approach, which emphasizes that the nation state still holds a privileged position in relation to citizenship. The nation state for example still decides who has access to the country, on citizenship rules and tests, and on distribution of welfare to social groups (Modood et al. 2006, Siim and Squires 2008).

The intersectional approach is a fruitful way to analyze inclusionary and exclusionary dimensions of citizenship focusing on the intersections of gender, class, ethnicity, and other categories. The challenge is to address the dynamic relations between citizenship's inclusionary claims and its exclusionary force in the local, the national, and the international arena (Lister et al. 2007).

The final point emphasizes that belonging/unbelonging are inextricably linked. Judith Butler observed that the construction of who 'belongs to' the nation state triggers a construction of who does not 'belong to' the nation state: “... if the state binds in the name of the nation, conjuring a certain version of the nation forcibly, if not powerfully, then it also unbinds, releases, expels, banishes" (Butler and Spivak 2007: 4-5).

\section{A MULTI-LEVEL AND CONTEXTUAL INTERSECTIONAL APPROACH}

This section explores two key questions in relation to the intersectional approach from the perspective of citizenship and politics of belonging. One refers to the dynamic relations between different levels of analysis; the other to contextualizing the various categories and the difference between them.

The introduction to this special issue proposes an analytical model which aims to structure intersectional analyses at macro, meso and micro levels. Below we elaborate on this model in order to illustrate the need to situate citizenship in relation to contemporary politics and feelings of belonging. It is inspired by Yuval-Davis' claim that belonging is a dynamic process between organizational and subjective factors, which constructs belonging at different analytical levels (Yuval-Davis 2006a: 199ff).

Comparative research is another inspiration for contextualizing intersectional analyses. This approach has shown how variations in legal traditions, political institutions and national histories have influenced relations between gender and class and the meaning of the public/private divide (Siim 2000, Lister et al. 2007). It has focused on the interactions of citizens' claims-making and political opportunity structures at the local, national and global levels (Hobson 2007). Globalization and migration have challenged this "path dependency', but the different citizenship/ migration and gender regimes still influence the meanings and intersections of social categories like class, gender, and ethnicity/race.

The proposed model aims to overcome the duality between system and discourse by recognizing that the dimensions of inequality themselves are dynamic and changing. This version of intersectionality understands that national political histories, which institutionalize class, race, and gender as dimensions of inequality, are open 
opportunity structures, which influence discourses in interactive, intersectional ways (Ferree 2009: 87-88).

The multi-level model below focuses on the concept of belonging in relation to citizenship. It expresses a dynamic and institutional understanding of intersectionality, which explores the relationships between gender and other forms of inequalities from a local, national and global perspective (Lister et al. 2007, Siim and Squires 2008). Thus, an intersectional approach to belonging can be located at different levels of analysis (Christensen 2009).

(a) Macro level refers to support of larger 'imagined' communities, ${ }^{1}$ for example national or religious communities, often associated with strong communal feelings. However, such communities often have a flipside - by signalling the strong 'we' they simultaneously exclude 'the others'. Imagined communities are therefore an important element in constructing the border between 'us and them'. Politics of belonging at the macro level refer to (dominant) political discourses and arguments about citizenship, welfare, gender equality, national identities, and democracy (Anderson 1983, Yuval-Davis 1997).

(b) Meso level refers to the association of social and political actors with collective organizations, e.g. political parties and social movements. It can be membership of specific organizations of people with similar interests, values or ideas, based on common interests, activities or feelings of belonging resulting in common claims and creation of new collective identities, for example in the workers' or the women's movements. Association may also be membership of institutionalized policies, e.g. political parties. Political identities at the meso level refer to political discourses embedded in specific organizations (Siim 2009).

(c) Micro level refers to 'lived citizenship', i.e. peoples' identities and practices in everyday life. At this level, 'belonging' refers to the identities of individuals, social groups or local communities based mainly on face-to-face-relations, which construct social distinctions in relation to who you identify with. Such belongings can be reflexive and deliberate but can also refer to underlying notions and social practices, which contribute to confirm existing prejudices, e.g. about class and race/ethnicity (Gullestad 2006, Christensen and Jensen 2010).

A contextual intersectional approach is based on the ability to distinguish between various kinds of differences. Several scholars have warned against the tendency to homologize the various categories and standardize social forms of differentiation with different logics, diverse effects and different ontological and epistemological status (Knapp 2005, Yuval-Davis 2006b). Social categories like gender, class and race are generally accepted as fundamental social forms of differentiation across different paradigms and disciplines. However, the status of these categories and their contextual nature needs to be explored further through intersectional analyses.

Gudrun Axel-Knapp (2005) has addressed the differences between various categories in relation to the arrival of the intersectional approach from the US to Germany. Her main point is that the travel metaphor applies not only to intersectionality but also to the categorical triad of 'raceclass-gender'. Knapp wants a greater focus on the diverse and contextual significances of categories in relation to the history of ideas. In relation to the feminist debate about the meaning of gender, Knapp emphasizes that notions of class and race have different meanings in the German and American contexts. One example is the category of race, which is a common basis for identity claims in the US, and the category 'Rasse', which is impossible to use in 
an affirmative way in Germany, both to describe others and as a basis for identity claims. This negative understanding relates back to the racist identity politics of $\mathrm{Na}$ tional Socialism (Knapp 2005: 257). Knapp points out that the class category also harbours large contextual differences. In the US context, class is the commonly used category for localization of social differences, whereas the German notion of 'Klasse' is almost exclusively used in relation to Marxist theory (Knapp 2005).

We conclude that all categories in 'the triad of race-class-gender' should be contextualized both as social structures and forms of identity. At the same time the analytical model above emphasizes that identities are not only shaped by social structures but influenced by institutions and collective organizations. From this perspective intersectionality is a tool to analyze the dynamic interactions of structures, institutions and identities at different levels (Jensen 2006, Phoenix 2006, Christensen and Siim 2006). ${ }^{2}$

To sum up, the contextual approach to citizenship and belonging has implications for the research strategy for analyzing the intersections between gender, ethnicity and national belongings. The first point is that the meanings and interactions of the selected categories, e.g. gender and ethnicity, are contextual and influenced by national histories, institutions and narratives about citizenship and politics of belonging. Secondly, a multidimensional and intersectional model was proposed as a tool to study the dynamics and tensions between macro, meso and micro relations. Finally, we propose a research strategy which analyses the dynamic intersections of inequalities at more than one analytical level, when studying individual identities, collective organizing and claims of national belongings.

\section{INTERSECTIONS OF GENDER AND ETHNICITY IN THE DEBATE ON HEADSCARVES}

This section looks briefly at intersectionality and contemporary politics of belonging in the Danish context with a focus on the intersections of gender and ethnicity. The debate on headscarves illustrates both potentials and problems in using intersectionality as an approach to study gender, ethnicity and the construction of 'Danishness'. We point to the problematic use of the intersecting categories in political debates, and as a way of overcoming this problem we propose a differentiation between various versions of intersectionality with different meanings and effects (Siim 2009, Agustin 2009). Inclusive framings of intersectionality take different categories into consideration and demonstrate awareness of the intersecting effects of simultaneous oppression in terms of gender and ethnicity. Exclusive framings of intersectionality give priority to one form of inequality (e.g. gender inequality) at the cost of highlighting the difference between 'them and us'. In this way, the use of the intersecting categories tends towards excluding other inequalities. This can lead to racist-ethnic-nationalistic biases concerning women who face multiple inequalities as is the case with migrant women in the Netherlands (see Lombardo and Verloo 2009: 78-79).

From a comparative historical perspective, the Nordic welfare states are said to belong to the same welfare and gender regime with universal social rights attached directly to citizenship (Siim and Borchorst 2008). During the last 25 years, migration from the Middle East and Africa has challenged the Nordic model to include new forms of diversity. ${ }^{3}$ Scholars conclude that despite differences in policies and discourses, immigrant groups tend to be marginalized on the labour market, in politics and in society compared to ethnic majorities in all the Nordic countries (Brochmann 
and Hagelund 2005). Debates about Muslim minorities often rely upon an underlying premise about the countries as normative models, not only in relation to democracy and social equality but also for gender equality (Gullestad 2006).

The countries have relatively accommodating approaches to headscarves in public institutions but there are important differences in the framing of the Muslim headscarf. These points will be illustrated first by looking at the Danish debate on the headscarf and secondly by comparing the reasoning in headscarf debates in Denmark and Norway (Siim and Skjeie 2008).

The meaning of Danish values has become a contested issue in the public discourse, and the intersection of gender and ethnicity is often used as a strong marker of 'Danishness'. Danish nationalism represents a particular civic nationalism, where the dominant political discourse equates Danish values with universalist civic values, and thus perceives democracy and egalitarianism as a Danish way of life (Mouritsen 2006: 7879). The official perception of gender equality has since the 1990s increasingly been associated with Danish values and constructed as something, which has already been achieved for the white majority. This understanding is used as an argument to exclude both Muslim men and women from the national community. Media debates often portray Muslim men as 'oppressors' and often perceive Muslim women as victims of 'their culture and religion' (see Andreassen 2005).

Research shows that the understanding of gender equality for native Danish women is often contrasted to the oppression of Muslim women wearing a veil (Andreassen 2005, Siim 2007). This has been the prevalent discourse in the arguments and rhetoric of The Danish People's Party [Dansk Folkeparti], a populist anti-immigration party. The party uses gender equality arguments in its criticism of ethnic minorities, even though it has never supported Danish gender equality policies.
One striking example is the use of gender equality arguments in several newspaper ads to position Muslim groups as 'outside' and 'unbelonging' to the Danish community, for instance with the picture of a burka-clad judge below, which signals a strong disapproval of the possibility that judges would be able to wear headscarves in Danish courtrooms.

\section{THI KENDES FOR RET}

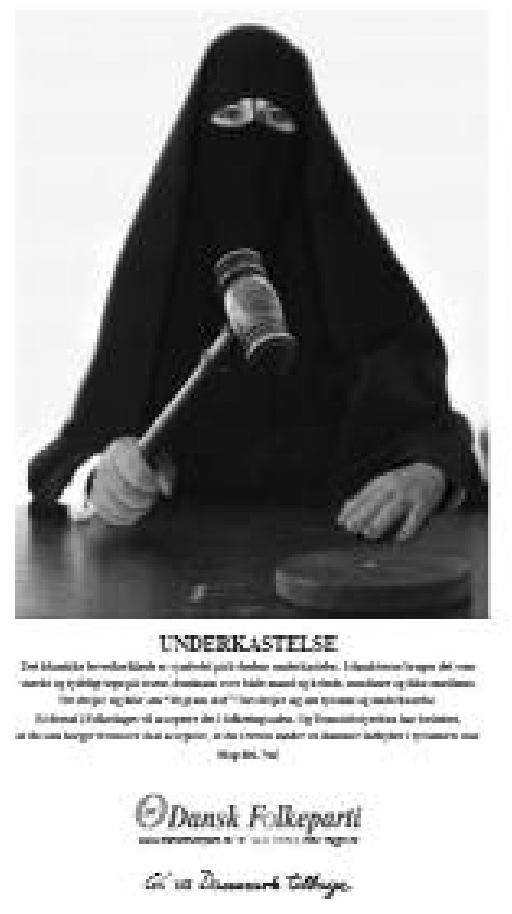

CDansk Folkeparti

The ad is entitled SUBMISSION. The subtext reads:

"The Islamic headscarf is a symbol of women's submission. The Islamists use it as a strong and visible sign of the dominance of faith over men and women, Muslims and non-Muslims. It is not only about " 30 grams of cloth". It is about tyranny and submission! 
A majority in Parliament is willing to accept this in Parliament, and the Independent Board of Judges has decided that you as a citizen in the future must accept that you in the courtroom can meet a judge cloaked in the tyranny of veil.”

The ad equals the headscarf with the burka. It ends with an emotional call to national feelings: 'Give us back Denmark'. 4

The ad raises questions about 'Danishness': Who 'we' are, and who is defined as 'the others'. The text makes it clear that it is the so-called 'Islamists' who symbolize women's submission and accept tyranny. The negative rhetoric constructs all Muslims as being outside 'Danishness'. In addition, the ad hints that somebody has taken Denmark away from 'us'. Considering who is constructed as 'the other', there can be no doubt as to who this is. But not only does the ad construct all Muslims as being outside the national Danish community. It also refers to an underlying assumption about ethnic Danish women's gender equality.

This can illustrate how the Danish People's Party uses 'politics of belonging' as a political project to define who is 'in' and who is 'out' in terms of the national community. It shows how the dominant understanding of gender equality is used to stigmatize and exclude immigrant women. In both cases the constructions rely on intersections of gender, ethnicity, and nationalism. This analysis arguably demonstrates how one version of intersectionality has been instrumentalized to exclude immigrant minorities. Keith Pringle (2006) uses the term 'abusing intersectionality' to emphasize how certain couplings of categories (here gender and ethnicity) can be applied to exclude marginalized groups.

A comparison of the hijab debates in Denmark and Norway can illustrate the variations in the framings of intersections of gender and ethnicity and in the regulations (see Siim and Skjeie 2008). In both coun- tries the case involved two conflicting principles: The right of employees to wear the hijab to work for religious reasons vs. employers' power to determine the dress-code in private companies. In Denmark the Supreme Court ruled that employers have the right to ban the veil from private companies if it is part of a general dress-code banning all religious symbols (in 2004). The decision was different in Norway where the Equality Ombud ruled that employers did not have the right to ban the hijab. The Danish case was presented as a balance between religious freedom and the power of employers with no articulation of intersectional framing and no reference to gender. The Norwegian Ombud referred to the intersection of direct religious discrimination with indirect gender discrimination, thus acknowledging that it is women who wear the headscarf. Siim and Skjeie point towards three explaining factors: a) the institutional difference between the Equality Ombud and the Supreme Court, b) the political mobilization in Norway which did not happen in Denmark, and finally c) the Norwegian tradition for religious pluralism which is absent in Denmark (Siim and Skjeie 2008: 333-34).

The cases can illustrate three different framings of the intersections of gender and ethnicity in public and political-legal debates: The rhetoric of the Danish People's Party on headscarves arguably expresses an exclusionary framing of intersectionality, which emphasizes one form of inequality in relation to gender while at the same time exacerbating other types of differences between 'them and us'. This contrasts with the reasoning of the Danish Supreme Court, which negotiates religion and the right of employers in an un-gendered way. Finally the framing of the Norwegian Ombud can be interpreted as an example of an inclusive framing of intersectionality, which integrates principles of gender equality with accommodation of the rights of religious minorities. 


\section{CONCLUSION}

First, we have argued that it is a challenge to gender and diversity research to develop a multi-level, contextual and dynamic understanding of intersectionality, which is able to link studies of individual identities at the micro level with meso level studies of organizations/institutions, and macro level studies of social structures and citizenship/migration and gender regimes.

Second, we have illustrated that the intersectional approach is double-edged: intersectionality can be a fruitful methodological approach for exploring assumptions about significant categories, for example gender and ethnicity in public, political debates and disclose underlying perceptions of nationality (e.g. about the gender equal Danish women). But at the same time the framing of intersectional arguments can be instrumentalized - and abused - in ways that serve exclusionary objectives. In addition we have stressed the contextual nature of social categories embedded in national institutions and belongings.

The article has argued that the Danish People's Party has presented intersectional arguments against women wearing a headscarf as part of an exclusionary framing, which constructs the headscarf as part of an oppressive Muslim culture and religion. The discourse about 'Danishness' is premised upon a distinction between 'them and us' with gender equality as a strong marker and on the underlying assumption about Danish democracy and 'gender equality' as normative models. The Norwegian Ombud's reasoning was presented as an example of an alternative inclusionary framing, which combines two sets of principles: gender equality and accommodation of religious minorities. From a democratic perspective this is a promising understanding of intersectionality because it refers to gender, ethnicity, and religion as multiple intersecting equality claims, not as contradictory and competing claims.

\section{Notes}

1. The idea of the nation/nation state as an imagined community was introduced by American scholar Benedict Anderson, who defines the nation as imagined "because the members of even the smallest nation will never know most of their fellow-members, meet them, or even hear of them, yet in the minds of each lives the image of their communion" (Anderson 1983: 15).

2. Leslie McCall has emphasized this argument about the differences among categories and stated that gender, class and race are relational categories. McCall distinguishes between three approaches within feminist theory: anti-categorical approach (represented primarily in poststructuralist theories); intra-categorical approach which focuses on differences within one of the categories (for instance black women in Crenshaw's analysis) and the intercategorical approach, which is McCall's own approach to studying interrelations between the categories. The latter position is inspired by quantitative analyses of intersecting inequality (McCall 2005).

3 . The countries have recently chosen different policies in relation to migration/integration. Sweden is the only Nordic country that calls itself multicultural and the only Nordic country to adopt dual citizenship (in 2001) and has separated state and church (2003) (Lister et al. 2007, see also Siim and Borchorst 2008).

4. Ad can be found at: http://www.danskfolkeparti.dk/pictures_org/DF-sloer-annonce4.pdf

\section{LITERATURE}

- Agustín, Lise Rolandsen (2009): “'It is all about the women': intertwining discourses on gender equality, ethno-national diversity and identity constructions among Danish politicians", EUROSPHERE Working paper, No. 22.

- Anderson, Benedict (1983): Imagined Communities. Reflections on the Origin and Spread of $\mathrm{Na}$ tionalism. Verso Editions and NLB, London.

- Andreassen, Rikke (2005): The Mass Media's Construction of Gender, Race, Sexuality and Nationality. An Analysis of the Danish News Media's Communication about Visible Minorities from 1971-2004. Department of History, University of Toronto.

. Beck, Ulrich (2002): "The Cosmopolitan Society and its Enemies", in: Theory, Culture \& Society 19(1-2). 
- Bellamy, Richard, Castiglione, Dario and Santoro, Emilio (eds.) (2003): Lineages of European Citizenship. Rights, Belonging and Participation in Eleven Nation-States. Palgrave/Macmillan, Basingstoke.

- Brochmann, Grethe and Hagelund, Anniken (2005): Innvandringens velferdspolitiske konsekvenser. Nordisk kunnskapsstatus. Nordic Council of Ministers, Copenhagen.

- Butler, Judith \& Spivak, Gaytri C. (2007): Who sings the nation-state? Language, politics, belonging. Seagull Books, New York.

- Christensen, Ann-Dorte \& Jensen, Sune Qvotrup (2010): "Intersektionalitet - nye udfordringer og muligheder for kvalitativ samfundsforskning", in: Michael Hviid Jacobsen \& Sune Qvotrup Jensen (eds.): Kvalitative udfordringer. Hans Reitzels Forlag (forthcoming), Copenhagen.

. Christensen, Ann-Dorte \& Siim, Birte (2006): "Fra køn til intersektionalitet - intersektionalitet i en dansk/nordisk kontekst", in Kvinder, Køn \& Forskning, 2006/2-3.

- Christensen, Ann-Dorte (2009): "Belonging and Unbelonging in an Intersectional Perspective", in: Gender, Technology and Development, 13(1).

. Crenshaw, Kimberle W. (1994): "Mapping the Margins - Intersectionality, Identity Politics and Violence against Women of Colour", in: Martha Finneman and Roxanne Mykitiuk (eds.): The Public Nature of Private Violence. The Discovery of Domestic Abuse. Routledge, London.

- Ferree, Myra Marx (2009): "Inequality, Intersectionality and the politics of discourse: framing feminist alliances", in: E. Lombardo, P. Meier and M. Verloo (eds.): The Discursive Politics of Gender Equality. Routledge, London.

- Gullestad, Marianne (2006): Plausible Prejudice: Everyday Practices and Social Images of Nation, Culture and Race. Universitetsforlaget, Oslo. - Hobson, Barbara (2007): "Recognition Struggles in Transnational Arenas: Negotiating Identities and Framing Citizenship", in: Critical Review of International Social and Political Philosophy, 10(4). - Jensen, S.Q. (2006): "Hvordan analysere sociale differentieringer?", in: Kvinder, Køn \& Forskning 2-3/2006.

- Knapp, Gudrun-Axeli (2005): "Race, Class, Gender: Reclaiming Baggage in Fast Travelling Theories", in: European Journal of Women's Studies 12. - Kymlicka, Will (1995): Multicultural Citizenship. Oxford University Press, Oxford.

- Lombardo, E. and M. Verloo (2009): "Stretching gender equality to other inequalities: political intersectionality in European gender equality policies", in: E. Lombardo, P. Meier and M. Verloo (eds.): The Discursive Politics of Gender Equality. Routledge, London.

- Lister, Ruth et al. (2007): Gendering Citizenship in Western Europe. New challenges for citizenship research in a cross-national context. Policy Press, Bristol.

- McCall, Leslie (2005): "The complexity of intersectionality", in: Signs 30(3).

- Modood, Tareq et al. (2006): Multiculturalism, Muslims and Citizenship. Routledge, Milton Park. - Mouritsen, Per (2006): "The particular universalism of a Nordic civic nation: common values, state religion and Islam in Danish political culture", in: Tareq Modood et al.: Multiculturalism, Muslims and Citizenship. Routledge, Milton Park.

- Phoenix, Ann (2006): "Interrogating intersectionality: Productive ways of theorizing multiple positioning", in: Kvinder, Køn \& Forskning 2006/2-3.

- Pringle, Keith (2006): "En fallstudie av bruket os missbruket av intersektionalitet", in: Kerstin Sandall and Diana Mulinari (eds.): Feministiske interventioner. Berättelser om och frän en annan värld. Atlas Akademi, Stockholm.

- Siim, Birte and Borchorst, Anette (2008): "The multicultural challenge to the Danish Welfare state - Social Politics, Equality and Regulating Families”, in: Janet Fink and Åsa Lundqvist (eds.): Changing Relations of Welfare: Family, Gender and Migration in Britain and Scandinavia. Ashgate Publishing, Aldershot.

- Siim, Birte and Skjeie, Hege (2008): "Tracks, intersections and dead ends. State feminism and multicultural retreats in Denmark and Norway", in: Ethnicities 8(3).

- Siim, Birte and Squires, Judith (eds.) (2008):

Contesting Citizenship. Routledge, London.

- Siim, Birte (2000): Gender and Citizenship. Politics and Agency in France, Britain and Denmark. Cambridge University Press, Singapore.

. Siim, Birte (2007): “The Challenge of Recognizing Diversity from the Perspective of Gender Equality: Dilemmas in Danish Citizenship", in: Critical Review of International, Social and Political Philosophy $2007 / 4$.

- Siim, Birte (2009): "Gender and Diversity in the European Public Sphere". EUROSPHERE Working Paper Series, No. 17.

- Soysal, Yasemin (1994): Limits of Citizenship. Migrants and Post-national Membership in Europe. University of Chicago Press, Chicago.

- Squires, Judith (2007): The New Politics of Gender Equality, Palgrave/Macmillan.

- Yuval-Davis, Nira (1997): Gender and Nation. Sage Publications, London. 
- Yuval-Davis, Nira (2006a): "Belonging and the politics of belonging", in: Pattern of Prejudice 2006/3, 197-214.

. Yuval-Davis, Nira (2006b): "Intersectionality and Feminist Politics", in: European Journal of Women's Studies 13, 193-209.

- Yuval-Davis, Nira (2007): "Intersectionality, Citizenship and Contemporary Politics of Belonging", in: Critical Review of International, Social and Political Philosophy 2007/4, 561-574.

\section{SUMMARY}

The article explores the intersectional approach to citizenship and politics of belonging focusing on the different framings of gender and ethnicity. It investigates the intersections of gender and ethnicity in the construction of national belongings. The hijab debates illustrate the contextual uses of intersectionality in public debates and illuminate the different framings of gender and ethnicity with both inclusionary and exclusionary effects. The argument is that political actors can (mis) use arguments about gender equality in order to construct social distinctions between 'them and us' - between the white gender equal majority and the oppressed Muslim women.

Ann-Dorte Christensen, Professor, PhD Department of Sociology, Social Work and Organisation

Aalborg University.

Birte Siim, Professor

Department of History, International and Social Studies

Aalborg University. 